\title{
Review Article \\ Gender Differences in Vogt-Koyanagi-Harada Disease and Sympathetic Ophthalmia
}

\author{
Yujuan Wang ${ }^{1,2}$ and Chi-Chao Chan ${ }^{1}$ \\ ${ }^{1}$ Immunopathology Section, Laboratory of Immunology, National Eye Institute, National Institutes of Health, \\ 10 Center Drive, 10/10N103, Bethesda, MD 20892-1857, USA \\ ${ }^{2}$ Zhongshan Ophthalmic Center, Sun Yat-sen University, Guangzhou 510060, China \\ Correspondence should be addressed to Chi-Chao Chan; chanc@nei.nih.gov
}

Received 30 September 2013; Revised 13 January 2014; Accepted 31 January 2014; Published 5 March 2014

Academic Editor: Janet L. Davis

Copyright (C) 2014 Y. Wang and C.-C. Chan. This is an open access article distributed under the Creative Commons Attribution License, which permits unrestricted use, distribution, and reproduction in any medium, provided the original work is properly cited.

\begin{abstract}
Vogt-Koyanagi-Harada disease (VKH) and sympathetic ophthalmia (SO) are types of T-cell mediated autoimmune granulomatous uveitis. Although the two diseases share common clinical features, they have certain differences in gender predilections. VKH classically has been reported as more prevalent in females than males, yet some studies in Japan and China have not found differences in gender prevalence. Male patients have a higher risk of chorioretinal degeneration, vitiligo, and worse prognosis. Conversely, the changing levels of estrogen/progesterone during pregnancy and the menstrual cycle as well as higher levels of TGF$\beta$ show a protective role in females. Potential causes of female predilection for VKH are associated with HLA-DR and HLA-DQ alleles. SO, a bilateral granulomatous uveitis, occurs in the context of one eye after a penetrating injury due to trauma or surgery. In contrast to the female dominance in $\mathrm{VKH}$, males are more frequently affected by $\mathrm{SO}$ due to a higher incidence of ocular injury, especially during wartime. However, no gender predilection of SO has been reported in postsurgical cases. No clinically different manifestations are revealed between males and females in SO secondary to either ocular trauma or surgery. The potential causes of the gender difference may provide hints on future treatment and disease evaluation.
\end{abstract}

\section{Introduction}

Vogt-Koyanagi-Harada disease (VKH) and sympathetic ophthalmia (SO) are both considered ocular T-cell mediated autoimmune diseases. Although the pathogenesis and etiologies are different, the two entities share common clinical manifestations as well as similar pathological and immunohistochemical features [1-3]. Moreover, prompt and thorough treatment is essential for both VKH and SO. Systemic presentations and clinical history are important features that differentiate VKH from SO. Extraocular findings such as dysacusis, vitiligo, poliosis often develop in VKH but are rare in SO. Since females are more susceptible to a variety of autoimmune diseases, such as systemic lupus erythematosus, multiple sclerosis, and rheumatoid arthritis [4-6], this paper reviews the literature of $\mathrm{VKH}$ and SO focusing on whether gender predilection exists in these two diseases.
1.1. Clinical Aspects of VKH. VKH disease is a multisystemic disorder that involves the eyes, ears, skin, hair, and meninges. Ocular manifestations are characterized by bilateral granulomatous panuveitis with exudative retinal detachments. In the majority of VKH patients, the second eye becomes involved within 2 weeks after initial presentation. Overall, females are more frequently affected with VKH than males [7-9], although several studies found no such gender predilection $[10,11]$. VKH tends to affect patients from Asian, Middle Eastern, Hispanic, and Native American populations [7, 12].

The typical progression of VKH includes 4 stages: the prodromal, uveitic, chronic, and chronic recurrent stages. The prodromal stage occurs 3-5 days before the ocular disease, mimicking a systemic viral-like presentation. The uveitic stage, which may last for several weeks to months, is characterized by acute anterior uveitis with mutton-fat keratic precipitates, aqueous cells and flare, iris nodules, 
and synechiae. Severe changes in the posterior segment include vitritis, optic disc swelling, retinal edema, hemorrhages, nonrhegmatogenous exudative retinal detachment, subretinal fibrosis, disciform scars, and RPE abnormality. The focal yellowish-white nodular lesions, known as DalenFuchs nodules, are presented at the subretinal pigment epithelium (RPE) level in the peripheral retina. The Hallmark findings in the uveitic stage are multifocal detachments of the neurosensory retina. Depigmentation of the perilimbus (Sugiura's sign) and a pale fundus (sunset-glow fundus) are revealed in the chronic stage. The chronic recurrent stage often presents other complications such as cataract, glaucoma, subretinal neovascularization, and subretinal fibrosis $[13,14]$. Recurrence mainly involves the anterior segment. Extraocular presentations including vitiligo, poliosis, alopecia, and dysacusis may also develop during the chronic or chronic recurrent stages.

1.2. Clinical Aspects of SO. SO is a rare bilateral granulomatous uveitis that occurs after the uvea of one eye is subjected to a penetrating injury due to trauma or surgery. The injury to one eye (known as the exciting eye) also results in an inflammatory response in the noninjured, contralateral eye (known as the sympathizing eye). Unlike the multisystemic involvements of $\mathrm{VKH}$, extraocular manifestations are rare in SO. Due to the rarity of disease and great improvements in modern surgical techniques, the disease rarely occurs; thus, it is difficult to estimate the prevalence of SO. An earlier study published the incidence of SO after a penetrating injury to be approximately $2 \%$ prior to 1950 [15]; lower incidences$0.2-0.5 \%$ following ocular trauma and $0.01 \%$ following ocular surgery-have been reported in more recent studies [16, 17]. The interval between ocular injury and the $\mathrm{SO}$ onset varies to a large extent, ranging from 5 days to 66 years $[16,18,19]$. In general, $65 \%$ of SO occurs between 2 weeks and 2 months after injury and $90 \%$ occurs within 1 year $[16,20]$.

The clinical presentations are identical in both traumaand injury-induced SO with an insidious onset. The classic presentation of SO is characterized by an acute granulomatous inflammation in the anterior segment with muttonfat keratic precipitates, aqueous cells and flare, iridocyclitis, and posterior synechiae. Moderate to severe vitritis with choroidal thickening and infiltration as well as optic disc swelling generally occurs in the posterior segment [21-24]. The presence of Dalen-Fuchs nodules, measuring 60 to $700 \mu \mathrm{m}$ in diameter, is typical and is most often found at the midperipheral retina in SO [25]. In extremely rare situations, patients with SO may experience extraocular symptoms, such as hearing loss, headache, vitiligo, and alopecia [26, 27].

\section{Gender and VKH}

2.1. Gender Differences in Prevalence and Incidence. Most studies have reported that females are affected with VKH more frequently than males (Table 1). Earlier studies in North America have noted that $60-78 \%$ of VKH patients are females $[10,12,13,28,29]$. By reviewing $75 \mathrm{VKH}$ patients seen at the National Eye Institute between 1978 and 1996, 78.7\% of patients were females [7]. In other areas, the recently reported proportions of affected females with $\mathrm{VKH}$ are $78.9 \%$ in Mexico [9]; 62.9-75\% in Saudi Arabia [8, 30, 31]; 65.3\% in Tunisia, North Africa [32]; 73.7\% in Japan [33]; 84.44\% in South India [34]; 70\% in Brazil [35]; and 71.1\% in Turkey [36]. Sukavatcharin et al. reported that females constituted $62.5 \%$ of patients in 48 case series in a Hispanic population [37].

However, some other studies did not show similar findings. Sasamoto et al. found that only $38 \%$ of patients were females in their 47 case series of VKH in a Japanese population [38]. Chen et al. and Hou et al. even reported more male patients in more than 500 Chinese with VKH $[11,39]$. However, no gender predisposition of the disease was also reported from the same group in other studies [40-45]. Other VKH studies have also reported no gender differences in prevalence; interestingly, most of these conclusions come from studies of Asian populations [46-49]. These data might indicate that there are geographic variations in the gender predilection in the VKH patients [13].

\subsection{Gender Differences in Clinical Manifestation after the} Prevalence/Incidence. Interestingly, ocular manifestations of $\mathrm{VKH}$ are variable and race dependent, and the "sunsetglow" appearance is more commonly seen in Hispanic and Asian patients [13]. A study of 134 eyes (67 VKH patients) conducted in Singapore reported that male VKH patients (50 eyes) were clinically associated with a higher risk of chorioretinal degeneration and vitiligo [47]. No other clinical differences have been reported in VKH between male and female patients.

2.3. Gender Differences in Prognosis. Several factors have been related to a better prognosis in female patients with VKH. Pregnancy is reported to play a role in VKH prognosis and has a beneficial effect on disease activity [10, 50-52]. In general, two patterns of prognosis during pregnancy have been described [10, 50-52]. In some females with VKH, the ophthalmic presentations improved during pregnancy, but with recurrence after delivery $[10,51,53]$. Several studies have documented less uveitis reactivity with lower numbers/rates of flare-up during pregnancy, but many of these females experienced a rebound in activity within 6 months of delivery [5355]. However, in the other cases, VKH developed in females during pregnancy who were then cured with corticosteroids without recurrence following delivery [50]. Because VKH is a T-cell mediated autoimmune disease, changes in immunity and humoral constituents during pregnancy may account for the remissions in female patients [51]. In addition, Elias et al. showed that better final visual acuity is positively correlated with female patients, whereas male gender in $\mathrm{VKH}$ is significantly associated with worse visual acuity [56].

\subsection{Possible Explanations for Gender Differences Found in VKH}

2.4.1. Relationship with Hormone Changes. Sex hormones, including estrogen and progesterone, are believed to mediate 
TABLE 1: Demographic differences of Vogt-Koyanagi-Harada disease (VKH) in the literature.

\begin{tabular}{|c|c|c|c|c|}
\hline Author/year & $\begin{array}{l}\text { Total: male }(\%) / \text { female }(\%) \\
P \text { value }\end{array}$ & $\begin{array}{l}\text { Age: mean } \pm \text { SD } \\
\text { (range, years) }\end{array}$ & Race or region & Reference \\
\hline Ohno et al./1977 & $\begin{array}{c}51: 23(45.1) / 28(54.9) \\
P=0.4852\end{array}$ & NA & $\begin{array}{l}\text { African American: } 13.7 \% \\
\text { Oriental: } 29.4 \% \\
\text { American Indian: } 7.8 \% \\
\text { Spanish American: } 15.7 \% \\
\text { White: } 29.4 \% \\
\text { Others: } 2(3.9 \%) \\
\end{array}$ & {$[12]$} \\
\hline Snyder and Tessler/1980 & $\begin{array}{c}20: 8(40) / 12(60) \\
P=0.3727\end{array}$ & $39.7(10-56)$ & $\begin{array}{l}\text { African American: } 11(55 \%) \\
\text { Hispanic: } 7(35 \%) \\
\text { White: } 2(10 \%)\end{array}$ & {$[10]$} \\
\hline Belfort Jr et al./1988 & $\begin{array}{l}33: 10(30) / 23(70) \\
P=0.0174^{* *}\end{array}$ & NA & $\begin{array}{l}\text { White: } 60 \% \\
\text { Darkly pigmented: } 24 \% \\
\text { Sansei: } 9 \% \\
\text { African American: } 6 \%\end{array}$ & {$[35]$} \\
\hline Sasamoto et al./1990 & $\begin{array}{c}47: 29(61.7) / 18(38.3) \\
P=0.1057\end{array}$ & $41.1(14-64)$ & Japan & [38] \\
\hline Beniz et al./1991 & $\begin{array}{c}48: 15(31.2) / 33(68.8) \\
\qquad P=0.0072^{* *}\end{array}$ & $33.4 \pm 14.5(15-78)$ & $\begin{array}{l}\text { Hispanic: } 75 \% \\
\text { White: } 10.4 \% \\
\text { African American: } 4.2 \% \\
\text { Oriental: } 10.4 \%\end{array}$ & {$[28]$} \\
\hline Rubsamen and Gass/1991 & $\begin{array}{l}22: 5(22.7) / 17(77.3) \\
\quad P=0.0060^{* *}\end{array}$ & $35(13-73)$ & $\begin{array}{l}\text { Hispanic: } 54 \% \\
\text { African American: } 23 \% \\
\text { White: } 14 \% \\
\text { Oriental: } 9 \% \\
\end{array}$ & [29] \\
\hline Moorthy et al./1995 & $\begin{array}{c}\text { 65: } 17(26.2) / 48(73.8) \\
P=0.0000^{* *}\end{array}$ & $32(7-71)$ & $\begin{array}{l}\text { Hispanic: } 51(78 \%) \\
\text { Asian: } 6(10 \%) \\
\text { African American: } 4(6 \%) \\
\text { Native American: } 1(1.5 \%) \\
\text { White: } 2(3 \%) \\
\text { Asian Indian: } 1(1.5 \%)\end{array}$ & {$[13]$} \\
\hline Lertsumitkul et al./1999 & $\begin{array}{c}75: 16(21.3) / 59(78.7) \\
P=0.0000^{* *}\end{array}$ & $32.8 \pm 12.6(11-72)$ & $\begin{array}{l}\text { White/native American: } 22.7 \% \\
\text { African/native: American: } \\
52.0 \% \\
\text { Hispanic: } 12.0 \% \\
\text { Oriental: } 12.0 \% \\
\text { Asian Indian: } 1.3 \% \\
\end{array}$ & {$[7]$} \\
\hline Sheu et al./2003 & $\begin{array}{c}39: 21(53.8) / 18(46.2) \\
P=0.6368\end{array}$ & $39.82 \pm 12.38$ & Taiwan & {$[75]$} \\
\hline Wakabayashi et al./2003 & $\begin{array}{c}19: 5(26.3) / 14(73.7) \\
P=0.0306^{* *}\end{array}$ & NA & Japanese & [33] \\
\hline Sheu et al./2004 & $\begin{array}{c}31: 19(61.3) / 12(38.7) \\
P=0.2063\end{array}$ & $38.6 \pm 10.6(20-63)$ & Taiwan Chinese & {$[76]$} \\
\hline $\begin{array}{l}\text { Tesavibul and } \\
\text { Sansanayuth/2005 }\end{array}$ & $\begin{array}{c}33: 12(36.4) / 21(63.6) \\
P=0.1142\end{array}$ & $35 \pm 13.4(17-67)$ & Thai & {$[48]$} \\
\hline Sukavatcharin et al./2007 & $\begin{array}{c}\text { 48: } 18(37.5) / 30(62.5) \\
\quad P=0.0801\end{array}$ & $35 \pm 13$ & Hispanic & {$[37]$} \\
\hline Chee et al./2007 & $\begin{array}{c}89: 38(42.1) / 51(57.9) \\
P=0.1347\end{array}$ & $41.8 \pm 14.7(\mathrm{SE})$ & $\begin{array}{l}\text { Chinese: } 75.28 \% \\
\text { Malays: } 14.61 \% \\
\text { Indians: } 5.62 \% \\
\text { Others: } 4.49 \% \text {; }\end{array}$ & {$[46]$} \\
\hline Khairallah et al./2007 & $\begin{array}{c}49: 17(34.7) / 32(65.3) \\
P=0.0291^{* *}\end{array}$ & $35(16-54)$ & North Africa & {$[32]$} \\
\hline Murthy et al./2007 & $\begin{array}{c}45: 7(15.6) / 38(84.4) \\
\quad P=0.0000^{* *}\end{array}$ & $37 \pm 14.2(14-63)$ & South India & {$[34]$} \\
\hline Tugal-Tutkun et al./2007 & $\begin{array}{c}\text { 45: } 13(28.9) / 32(71.1) \\
P=0.0032^{* *}\end{array}$ & $31 \pm 14.3(4-65)$ & Turkish & {$[36]$} \\
\hline
\end{tabular}


TABle 1: Continued.

\begin{tabular}{|c|c|c|c|c|}
\hline Author/year & $\begin{array}{c}\text { Total: } \\
\text { male }(\%) / \text { female }(\%) ; P \text { value }\end{array}$ & $\begin{array}{l}\text { Age: mean } \pm \mathrm{SD} \\
\text { (range, years) }\end{array}$ & Race or region & Reference \\
\hline Kiyomoto et al./2007 & $\begin{array}{c}68: 29(42.6) / 39(57.4) \\
P=0.2215\end{array}$ & $43.1 \pm 14.2(16-71)$ & Japanese & {$[77]$} \\
\hline Al-Kharashi et al./2007 & $\begin{array}{l}\text { 68: } 17(25) / 51(75) \\
P=0.0000^{* *}\end{array}$ & $25 \pm 10.3(7-55)$ & Saudi Arabia & {$[31]$} \\
\hline Hou et al./2008* & $\begin{array}{c}\text { 231: } 128(55.4) / 103(44.6) \\
P=0.1001\end{array}$ & $33.6 \pm 12.4$ & Chinese & {$[40]$} \\
\hline Chee et al./2009 & $\begin{array}{c}67: 27(40.3) / 40(59.7) \\
P=0.1103\end{array}$ & $42.3(5.4-70.9)$ & $\begin{array}{l}\text { Chinese: } 79.1 \% \\
\text { Others: } 20.9 \% \\
\end{array}$ & {$[47]$} \\
\hline Lai et al./2009 & $\begin{array}{c}\text { 35: } 18(51.4) / 17(48.6) \\
P=0.8694\end{array}$ & $42.5 \pm 18.4(10-72)$ & Hong Kong Chinese & {$[78]$} \\
\hline Iqniebi et al./2009 & $\begin{array}{c}30: 12(40) / 18(60) \\
P=0.2727\end{array}$ & NA & Saudi Arabia & {$[69]$} \\
\hline Meng et al./2009* & $\begin{array}{c}247: 138(55.9) / 109(44.1) \\
P=0.0630\end{array}$ & 33.6 & Chinese & {$[41]$} \\
\hline Hou et al./2009* & $\begin{array}{c}\text { 307: } 171(55.7) / 136(44.3) \\
P=0.0453^{* *}\end{array}$ & $34.3 \pm 10.3$ & Chinese & {$[39]$} \\
\hline Hu et al./2010* & $\begin{array}{c}379: 197(51.9) / 182(48.1) \\
P=0.4596\end{array}$ & $32.8 \pm 9.8$ & Chinese & {$[43]$} \\
\hline Chee et al./2010 & $\begin{array}{c}28: 13(46.4) / 15(53.6) \\
P=0.7055\end{array}$ & 42.2 (median) (16-77) & $\begin{array}{l}\text { Chinese: } 64.3 \% \\
\text { Malays: } 21.5 \% \\
\text { Indians: } 7.1 \% \\
\text { Others } 7.1 \%\end{array}$ & {$[79]$} \\
\hline Jiang et al./2010* & $\begin{array}{c}382: 210(55) / 172(45) \\
P=0.0502\end{array}$ & $33.6 \pm 12.4$ & Chinese & {$[42]$} \\
\hline Shu et al. $/ 2010^{*}$ & $\begin{array}{c}\text { 385: } 201(52.2) / 184(47.8) \\
P=0.3880\end{array}$ & $34.1 \pm 9.6$ & Chinese & {$[44]$} \\
\hline Aláez et al./2011 & $\begin{array}{c}\text { 76: } 16(21.1) / 60(78.9) \\
P=0.0000^{* *}\end{array}$ & $42.1(11-76)$ & Mexican Mestizos & {$[9]$} \\
\hline Al-Halafi et al./2011 & $\begin{array}{c}\text { 256: } 95(37.1) / 161(62.9) \\
P=0.0000^{* *}\end{array}$ & $29 \pm 13$ & Saudi Arabia & {$[8]$} \\
\hline Chen et al./2012* & $\begin{array}{c}\text { 519: } 290(55.9) / 229(44.1) \\
P=0.0070^{* *}\end{array}$ & $30.0 \pm 13.5$ & Chinese & {$[11]$} \\
\hline Yang et al./2012 & $\begin{array}{c}38: 17(44.7) / 21(55.3) \\
P=0.5152\end{array}$ & $50 \pm 8.4$ & Hong Kong Chinese & {$[80]$} \\
\hline Chen et al./2012* & $\begin{array}{c}\text { 451: } 243(53.9) / 208(46.1) \\
P=0.0973\end{array}$ & $33.8 \pm 9.3$ & Chinese & {$[45]$} \\
\hline Morita et al./2013 & $\begin{array}{c}85: 37(43.5) / 48(56.5) \\
P=0.2301\end{array}$ & $47.1 \pm 14$ & Japanese & {$[81]$} \\
\hline Alam et al./2013 & $\begin{array}{c}\text { 9: } 4(44.4) / 5(55.6) \\
P=0.7440\end{array}$ & $28(16-43)$ & Pakistanis: & {$[49]$} \\
\hline
\end{tabular}

${ }^{*}$ Study from the same VKH research group in China; ${ }^{* *} P<0.05$.

the immune response and account for gender differences in the prevalence of autoimmune diseases [57]. An increased incidence or severity of inflammation has been reported in the late phase of the menstrual cycle for women with asthma, rheumatoid arthritis, and psoriatic arthritis [58-61]. As a systemic autoimmune disorder and subtype of uveitis, $\mathrm{VKH}$ is also influenced by hormonal factors $[61,62]$.

Literature showing $\mathrm{VKH}$ amelioration during pregnancy has suggested that sex hormones may influence the course of VKH $[10,51]$. To further evaluate the protective role of pregnancy, we used the experimental autoimmune uveitis
(EAU) mouse model mimicking human uveitis [63]. Our results suggest that protection from EAU during pregnancy is primarily due to a selective reduction of antigen-specific Th1 responses with only marginal enhancement of Th2 function. These effects may in part be secondary to elevated systemic levels of TGF- $\beta$. We measured serum levels of the female hormones (estrogen, progesterone, and prolactin), Th1 (IL2 and IFN- $\gamma$ ), Th2 (IL-4, IL-5, IL-6, and IL-10), and TGF$\beta$ cytokine levels in 4 women with uveitis during their 5 normal, full term pregnancies. Uveitic activities decreased after the first trimester but flared up in early postpartum 
TABLE 2: Demographic differences of sympathetic ophthalmia (SO) in the literature.

\begin{tabular}{|c|c|c|c|c|c|}
\hline Author/year & $\begin{array}{c}\text { Total: } \\
\text { male }(\%) / \text { female }(\%) \\
P \text { value }\end{array}$ & $\begin{array}{l}\text { Age: mean } \pm \mathrm{SD} \\
\text { (range, years) }\end{array}$ & Cause of SO & Race or region & Reference \\
\hline Chan et al./1995 & $\begin{array}{c}32: 16(50) / 16(50) \\
P=1.0000\end{array}$ & $32.7 \pm 23.6(1-80)$ & $\begin{array}{l}\text { Trauma: } 23(71.9 \%) \\
\text { Surgery: } 9(28.1 \%)\end{array}$ & NA & {$[74]$} \\
\hline Lin and Zhong/1996 & $\begin{array}{c}30: 21(70) / 9(30) \\
P=0.0235^{*}\end{array}$ & $32.3(6-66)$ & $\begin{array}{l}\text { Trauma: } 24(80 \%) \\
\text { Surgery: } 6(20 \%)\end{array}$ & Chinese & {$[71]$} \\
\hline $\begin{array}{l}\text { Castiblanco and } \\
\text { Adelman/2009 }\end{array}$ & $\begin{array}{c}86: 62(72.1) / 24(27.9) \\
P=0.2655\end{array}$ & $46(3-83)$ & $\begin{array}{c}\text { Trauma: } 40(46.5 \%) \\
\text { Surgery: } 38(44.2 \%) \\
\text { Trauma + surgery: } \\
8(9.3 \%)\end{array}$ & NA & {$[72]$} \\
\hline Galor et al./2009 & $\begin{array}{c}85: 50(60) / 35(40) \\
\quad P=0.0633\end{array}$ & $44(2-91)$ & $\begin{array}{l}\text { Trauma: } 53 \text { (62.4\%) } \\
\text { Surgery: } 32(37.6)\end{array}$ & $\begin{array}{c}\text { White: } 57 \% \\
\text { African American: } 23 \% \\
\text { Others: } 20 \% \\
\end{array}$ & [73] \\
\hline Al-Halafi et al./2011 & $\begin{array}{c}60: 34(56.7) / 26(43.3) \\
P=0.2992\end{array}$ & $36 \pm 20(4-90)$ & NA & Saudi Arabia & {$[8]$} \\
\hline
\end{tabular}

period, suggesting an association of female hormones and elevated TGF- $\beta$ with uveitis [64].

In addition, Sanghvi et al. evaluated 76 regularly menstruating women with acute anterior uveitis and found that the disease commences more frequently in the postovulatory phase of the menstrual cycle [61]. They concluded that the onset of the acute anterior uveitis is partially dependent on the levels of estrogen and/or progesterone. The withdrawal of these hormones, with their proven anti-inflammatory effects, may provoke the onset of uveitis.

Based on the association of pregnancy and menstrual cycle with $\mathrm{VKH}$, it is important to assess the menstrual history and to consider adjustments of immunosuppressants, such as corticosteroid treatment, during pregnancy and postpartum [51].

2.4.2. Relationship with HLA-DR Genes. Although the precise mechanism of $\mathrm{VKH}$ is still not clear, genetic factors are thought to play an important role in $\mathrm{VKH}[61,62]$. The associations of HLA-DR53, HLA-DR4, and HLA-DQ4 antigens with VKH have been reported [65-68]. Additionally, a strong association with HLA-DRB1*04:05 allele has been documented in VKH $[69,70]$. Recently, Aláez et al. in Mexico compared $76 \mathrm{VKH}$ patients (78.9\% females) and 256 healthy controls using the HLA-DQB1/DRB1 genotyping method [9]. They found that HLA-DRB $1 * 04: 05$, HLA-DRB1*04:04, and HLA-DQB1*03:02 alleles were restricted only to female gender. This study implies a significant association with female gender and HLA in VKH.

\section{Gender and SO}

3.1. Gender Differences in Prevalence/Incidence and Possible Explanation. In trauma-induced SO, males are reported to have a higher prevalence than females [71]; this gender predominance may be attributable to a higher incidence of ocular injury in males, especially during historical wartime [72]. Galor et al. reviewed 85 patients with SO and showed a slight male predilection of male gender $(60 \%)$ with a higher incidence of traumatic etiology (62\%) [73]. We reviewed 32 patients with SO presented at the National Eye Institute, including 23 patients with SO resulting from trauma and 9 resulting from surgery. The numbers of males and females are equally distributed in the case series from 1982 to 1992 [74]. Al-Halafi et al. reported no gender difference in disease incidence in 34 males and 26 females with SO due to ocular injury during a 10-year period in Saudi Arabia [8]. Table 2 summarizes the demographics of SO patients resulting from trauma and surgery. Interestingly, only one report shows significant male predisposition of 30 SO patients [71]. Overall, no gender predilection of SO has been reported in postsurgical cases. This is due to the fact that intraocular surgeries including glaucoma surgery, cataract extraction, and pars plana vitrectomy are equally performed in both male and female patients $[20,74]$.

3.2. Gender Differences in Clinical Manifestation after the Prevalence/Incidence. There are no clinical differences between males and females in SO due to either trauma or ocular surgery.

3.3. Gender Differences in Prognosis. Due to the rarity of SO, it is difficult to compare gender differences in the prognosis of SO. However, because SO and VKH share many clinical and pathological similarities, the role of sex hormone and pregnancy could also affect disease severity and presentation, Further clinical and/or experimental studies are required to draw a conclusion.

\section{Conclusions}

Both VKH and SO are types of bilateral granulomatous panuveitis that can lead to severe visual loss without effective management. In addition to clinical features, gender predilection in $\mathrm{VKH}$ and $\mathrm{SO}$ could provide more appropriate therapies for patients. In $\mathrm{VKH}$, with the protective role of 
estrogen/progesterone, female patients are better protected and have better prognoses. Moreover, the evidence that certain HLA-DR alleles are exclusively associated with $\mathrm{VKH}$ in females implies an important genetic background in the pathogenesis of $\mathrm{VKH}$. In $\mathrm{SO}$, although gender differences only exist in the incidence of ocular trauma, we cannot rule out the possible role of gender-based factors in the initiation, progression, and prognosis of SO. Additional gender-based studies may identify other genes or risk factors related to these two autoimmune diseases.

\section{Conflict of Interests}

The authors declare that there is no conflict of interests regarding the publication of this paper.

\section{References}

[1] N. A. Rao and A. R. Irvine Jr., "Mechanisms of inflammatory response in sympathetic ophthalmia and VKH syndrome," Eye, vol. 11, no. 2, pp. 213-216, 1997.

[2] C. C. Chan, S. M. Whitcup, and R. B. Nussenblatt, "Sympathetic ophthalmia and Vogt-Koyanagi-Harada syndrome," in Duane's Clinical Ophthalmology, W. Tasman and E. A. Jaeger, Eds., Lippincott, Williams and Wilkins Publishers, Philadelphia, Pa, USA, 2010.

[3] R. B. Nussenblatt, "Uveitic conditions not caused by active infection," in Uveitis: Fundamentals and Clinical Practice, R. B. Nussenblatt and S. M. Whitcup, Eds., pp. 289-318, Mosby, Philadelphia, Pa, USA, 4th edition, 2010.

[4] R. Voskuhl, "Sex differences in autoimmune diseases," Biology of Sex Differences, vol. 2, no. 1, 2011.

[5] N. Gleicher and D. H. Barad, "Gender as risk factor for autoimmune diseases," Journal of Autoimmunity, vol. 28, no. 1 , pp. 1-6, 2007.

[6] D. L. Jacobson, S. J. Gange, N. R. Rose, and N. M. H. Graham, "Epidemiology and estimated population burden of selected autoimmune diseases in the United States," Clinical Immunology and Immunopathology, vol. 84, no. 3, pp. 223-243, 1997.

[7] S. Lertsumitkul, S. M. Whitcup, R. B. Nussenblatt, and C.-C. Chan, "Subretinal fibrosis and choroidal neovascularization in Vogt-Koyanagi-Harada syndrome," Graefe's Archive for Clinical and Experimental Ophthalmology, vol. 237, no. 12, pp.1039-1045, 1999.

[8] A. Al-Halafi, H. A. Dhibi, I. H. Hamade, C. T. Bou Chacra, and K. F. Tabbara, "The association of systemic disorders with Vogt-Koyanagi-Harada and sympathetic ophthalmia," Graefe's Archive for Clinical and Experimental Ophthalmology, vol. 249, no. 8, pp. 1229-1233, 2011.

[9] C. Aláez, H. Flores-A, L. E. Concha del Río et al., "Major histocompatibility complex and strong human leukocyte antigenDRB1 and gender association with Vogt-Koyanagi-Harada syndrome in Mexican Mestizos," Human Immunology, vol. 72, no. 12, pp. 1198-1203, 2011.

[10] D. A. Snyder and H. H. Tessler, "Vogt-Koyanagi-Harada syndrome," The American Journal of Ophthalmology, vol. 90, no. 1, pp. 69-75, 1980.

[11] F. Chen, S. Hou, Z. Jiang et al., "CD40 gene polymorphisms confer risk of Behçet's disease but not of Vogt-Koyanagi-Harada syndrome in a Han Chinese population," Rheumatology, vol. 51, no. 1, Article ID ker345, pp. 47-51, 2012.
[12] S. Ohno, D. H. Char, S. J. Kimura, and G. R. O'Connor, "VogtKoyanagi-Harada syndrome," The American Journal of Ophthalmology, vol. 83, no. 5, pp. 735-740, 1977.

[13] R. S. Moorthy, H. Inomata, and N. A. Rao, "Vogt-KoyanagiHarada syndrome," Survey of Ophthalmology, vol. 39, no. 4, pp. 265-292, 1995.

[14] H. Inomata and M. Kato, "Vogt-Koyanagi-Harada disease," in Handbook of Clinical Neurology, P. J. Vinken, G. W. Bruyn, and H. L. Klawans, Eds., pp. 611-626, Elsevier, Amsterdam, The Netherlands, 12th edition, 1989.

[15] S. Duke-Elder and E. S. Perkins, "Sympathetic ophthalmitis," in Diseases of the Uveal Tract, S. Duke-Elder, Ed., pp. 558-593, Mosby, St. Louis, Mo, USA, 9th edition, 1966.

[16] M. A. Zaharia, J. Lamarche, and M. Laurin, "Sympathetic uveitis 66 years after injury," Canadian Journal of Ophthalmology, vol. 19, no. 5, pp. 240-243, 1984.

[17] G. E. Marak Jr., "Recent advances in sympathetic ophthalmia," Survey of Ophthalmology, vol. 24, no. 3, pp. 141-156, 1979.

[18] J. R. Lubin, D. M. Albert, and M. Weinstein, "Sixty-five years of sympathetic ophthalmia: a clinicopathological review of 105 cases (1913-1978)," Ophthalmology, vol. 87, no. 2, pp. 109-121, 1980.

[19] K. A. McClellan, F. A. Billson, and M. Filipic, "Delayed onset sympathetic ophthalmia," Medical Journal of Australia, vol. 147, no. 9, pp. 451-454, 1987.

[20] H. Goto and N. A. Rao, "Sympathetic ophthalmia and VogtKoyanagi-Harada syndrome," International Ophthalmology Clinics, vol. 30, no. 4, pp. 279-285, 1990.

[21] V. Gupta, A. Gupta, and M. R. Dogra, "Posterior sympathetic ophthalmia: a single centre long-term study of 40 patients from North India," Eye, vol. 22, no. 12, pp. 1459-1464, 2008.

[22] A. M. Abu El-Asrar, H. Al Kuraya, and A. Al-Ghamdi, "Sympathetic ophthalmia after successful retinal reattachment surgery with vitrectomy," European Journal of Ophthalmology, vol. 16, no. 6, pp. 891-894, 2006.

[23] A. M. Abu El-Asrar and S. A. Al-Obeidan, "Sympathetic ophthalmia after complicated cataract surgery and intraocular lens implantation," European Journal of Ophthalmology, vol. 11, no. 2, pp. 193-196, 2001.

[24] X. K. Chu and C. C. Chan, "Sympathetic ophthalmia: to the twenty-first century and beyond," Journal of Ophthalmic Inflammation and Infection, vol. 3, no. 1, article 49, 2013.

[25] M. Reynard, R. S. Riffenburgh, and D. S. Minckler, "Morphological variation of Dalen-Fuchs nodules in sympathetic ophthalmia," British Journal of Ophthalmology, vol. 69, no. 3, pp. 197-201, 1985.

[26] C. T. Chuang, P. S. Huang, S. C. Chen, and S. J. Sheu, "Reversible alopecia in Vogt-Koyanagi-Harada disease and sympathetic ophthalmia," Journal of Ophthalmic Inflammation and Infection, vol. 3, no. 1, article 41, 2013.

[27] D. J. Kilmartin, A. D. Dick, and J. V. Forrester, "Sympathetic ophthalmia risk following vitrectomy: should we counsel patients?" British Journal of Ophthalmology, vol. 84, no. 5, pp. 448-449, 2000.

[28] J. Beniz, D. J. Forster, J. S. Lean, R. E. Smith, and N. A. Rao, "Variations in clinical features of the Vogt-Koyanagi-Harada syndrome," Retina, vol. 11, no. 3, pp. 275-280, 1991.

[29] P. E. Rubsamen and J. D. M. Gass, "Vogt-Koyanagi-Harada syndrome: clinical course, therapy, and long-term visual outcome," Archives of Ophthalmology, vol. 109, no. 5, pp. 682-687, 1991. 
[30] H. S. Al-Mezaine, D. Kangave, and A. M. Abu El-Asrar, "Patterns of uveitis in patients admitted to a university hospital in Riyadh, Saudi Arabia," Ocular Immunology and Inflammation, vol. 18, no. 6, pp. 424-431, 2010.

[31] A. S. Al-Kharashi, H. Aldibhi, H. Al-Fraykh, D. Kangave, and A. M. Abu El-Asrar, "Prognostic factors in Vogt-Koyanagi-Harada disease," International Ophthalmology, vol. 27, no. 2-3, pp. 201210, 2007.

[32] M. Khairallah, S. B. Yahia, A. Ladjimi et al., "Pattern of uveitis in a referral centre in Tunisia, North Africa," Eye, vol. 21, no. 1, pp. 33-39, 2007.

[33] T. Wakabayashi, Y. Morimura, Y. Miyamoto, and A. A. Okada, "Changing patterns of intraocular inflammatory disease in Japan," Ocular Immunology and Inflammation, vol. 11, no. 4, pp. 277-286, 2003.

[34] S. I. Murthy, M. R. Moreker, V. S. Sangwan, R. C. Khanna, and S. Tejwani, "The spectrum of Vogt-Koyanagi-Harada disease in South India," International Ophthalmology, vol. 27, no. 2-3, pp. 131-136, 2007.

[35] R. Belfort Jr., M. Nishi, S. Hayashi, M. T. Abreu, A. M. N. Petrilli, and R. C. A. Plut, "Vogt-Koyanagi-Harada's disease in Brazil," Japanese Journal of Ophthalmology, vol. 32, no. 3, pp. 344-347, 1988.

[36] I. Tugal-Tutkun, Y. Ozyazgan, Y. A. Akova et al., "The spectrum of Vogt-Koyanagi-Harada disease in Turkey: VKH in Turkey," International Ophthalmology, vol. 27, no. 2-3, pp. 117-123, 2007.

[37] S. Sukavatcharin, J. H. Tsai, and N. A. Rao, "Vogt-KoyanagiHarada disease in hispanic patients," International Ophthalmology, vol. 27, no. 2-3, pp. 143-148, 2007.

[38] Y. Sasamoto, S. Ohno, and H. Matsuda, "Studies on corticosteroid therapy in Vogt-Koyanagi-Harada disease," Ophthalmologica, vol. 201, no. 3, pp. 162-167, 1990.

[39] S. Hou, P. Yang, L. Xie, L. Du, H. Zhou, and Z. Jiang, "Monocyte chemoattractant protein (MCP)-1-2518 A/G SNP in Chinese Han patients with VKH syndrome," Molecular Vision, vol. 15, pp. 1537-1541, 2009.

[40] S. Hou, P. Yang, L. Du et al., "Small ubiquitin-like modifier 4 (SUMO4) polymorphisms and Vogt-Koyanagi-Harada (VKH) syndrome in the Chinese Han population," Molecular Vision, vol. 14, pp. 2597-2603, 2008.

[41] Q. Meng, X. Liu, P. Yang et al., "PDCD1 genes may protect against extraocular manifestations in Chinese Han patients with Vogt-Koyanagi-Harada syndrome," Molecular Vision, vol. 15, pp. 386-392, 2009.

[42] Z. Jiang, P. Yang, S. Hou, F. Li, and H. Zhou, "Polymorphisms of IL23R and Vogt-Koyanagi-Harada syndrome in a Chinese Han population," Human Immunology, vol. 71, no. 4, pp. 414417, 2010.

[43] K. Hu, P. Yang, Z. Jiang, S. Hou, L. Du, and F. Li, "STAT4 polymorphism in a Chinese Han population with Vogt-KoyanagiHarada syndrome and Behçet's disease," Human Immunology, vol. 71, no. 7, pp. 723-726, 2010.

[44] Q. Shu, P. Yang, S. Hou et al., "Interleukin-17 gene polymorphism is associated with Vogt-Koyanagi-Harada syndrome but not with Behçet's disease in a Chinese Han population," Human Immunology, vol. 71, no. 10, pp. 988-991, 2010.

[45] Y. Chen, P. Yang, F. Li et al., "Association analysis of TGFBR3 gene with Vogt-Koyanagi-Harada disease and Behcet's disease in the Chinese Han population," Current Eye Research, vol. 37, no. 4, pp. 312-317, 2012.
[46] S.-P. Chee, A. Jap, and K. Bacsal, "Spectrum of Vogt-KoyanagiHarada disease in Singapore," International Ophthalmology, vol. 27, no. 2-3, pp. 137-142, 2007.

[47] S.-P. Chee, A. Jap, and K. Bacsal, "Prognostic factors of VogtKoyanagi-Harada disease in Singapore," The American Journal of Ophthalmology, vol. 147, no. 1, pp. 154.e1-161.e1, 2009.

[48] N. Tesavibul and W. Sansanayuth, "Vogt-Koyanagi-Harada disease in thai patients," Journal of the Medical Association of Thailand, vol. 88, no. 9, pp. S26-S30, 2005.

[49] M. Alam, M. Iqbal, B. S. Khan, and I. Hussain, "Vogt Koyanagi Harada disease: treatment and visual prognosis," Journal of the College of Physicians and Surgeons Pakistan, vol. 23, no. 10, pp. 740-742, 2013.

[50] Z. Friedman, M. Granat, and E. Neumann, "The syndrome of Vogt-Koyanagi-Harada and pregnancy," Metabolic Ophthalmology, vol. 4, no. 3, pp. 147-149, 1980.

[51] L. P. Steahly, "Vogt-Koyanagi-Harada syndrome and pregnancy," Annals of ophthalmology, vol. 22, no. 2, pp. 59-62, 1990.

[52] M. Nohara, K. Norose, and K. Segawa, "Vogt-Koyanagi-Harada disease during pregnancy," British Journal of Ophthalmology, vol. 79, no. 1, pp. 94-95, 1995.

[53] N. P. Chiam, A. J. Hall, R. J. Stawell, L. Busija, and L. L. Lim, “The course of uveitis in pregnancy and postpartum," British Journal of Ophthalmology, vol. 97, no. 10, pp. 1284-1288, 2013.

[54] P. K. Rabiah and A. T. Vitale, "Noninfectious uveitis and pregnancy," The American Journal of Ophthalmology, vol. 136, no. 1, pp. 91-98, 2003.

[55] L. I. Kump, R. A. Cervantes-Castañeda, S. N. Androudi, C. S. Foster, and W. G. Christen, "Patterns of exacerbations of chronic non-infectious uveitis in pregnancy and puerperium," Ocular Immunology and Inflammation, vol. 14, no. 2, pp. 99-104, 2006.

[56] A. Elias, M. Gopalakrishnan, S. Bhat, and G. Anantharaman, "Vogt-Koyanagi-Harada disease clinical course, therapy, complications and prognostic factors," World Journal of Retina and Vitreous, vol. 2, no. 2, pp. 46-52, 2012.

[57] D. Fairweather, S. Frisancho-Kiss, and N. R. Rose, "Sex differences in autoimmune disease from a pathological perspective," The American Journal of Pathology, vol. 173, no. 3, pp. 600-609, 2008.

[58] K. S. Tan, "Premenstrual asthma: epidemiology, pathogenesis and treatment," Drugs, vol. 61, no. 14, pp. 2079-2086, 2001.

[59] S. R. Rudge, I. C. Kowanko, and P. L. Drury, "Menstrual cyclicity of finger joint size and grip strength in patients with rheumatoid arthritis," Annals of the Rheumatic Diseases, vol. 42, no. 4, pp. 425-430, 1983.

[60] H. P. Stevens, L. S. Ostlere, C. M. Black, H. S. Jacobs, and M. H. A. Rustin, "Cyclical psoriatic arthritis responding to antioestrogen therapy," British Journal of Dermatology, vol. 129, no. 4, pp. 458-460, 1993.

[61] C. Sanghvi, K. Aziz, and N. P. Jones, "Uveitis and the menstrual cycle," Eye, vol. 18, no. 5, pp. 451-454, 2004.

[62] G. R. O'Connor, "Factors related to the initiation and recurrence of uveitis," The American Journal of Ophthalmology, vol. 96, no. 5, pp. 577-599, 1983.

[63] R. K. Agarwal, C.-C. Chan, B. Wiggert, and R. R. Caspi, "Pregnancy ameliorates induction and expression of experimental autoimmune uveitis," Journal of Immunology, vol. 162, no. 5, pp. 2648-2654, 1999.

[64] C.-C. Chan, G. F. Reed, Y. Kim, E. Agrón, and R. R. Buggage, "A correlation of pregnancy term, disease activity, serum female hormones, and cytokines in uveitis," British Journal of Ophthalmology, vol. 88, no. 12, pp. 1506-1509, 2004. 
[65] S. M. Monowarul Islam, J. Numaga, K. Matsuki, Y. Fujino, H. Maeda, and K. Masuda, "Influence of HLA-DRB1 gene variation on the clinical course of Vogt- Koyanagi-Harada disease," Investigative Ophthalmology and Visual Science, vol. 35, no. 2, pp. 752-756, 1994.

[66] S. M. M. Islam, J. Numaga, Y. Fujino et al., "HLA class II genes in Vogt-Koyanagi-Harada disease," Investigative Ophthalmology and Visual Science, vol. 35, no. 11, pp. 3890-3896, 1994.

[67] X. Y. Z. Xiao Yan Zhang, X.-M. Wang, and T.-S. Hu, "Profiling human leukocyte antigens in Vogt-Koyanagi-Harada syndrome," The American Journal of Ophthalmology, vol. 113, no. 5, pp. 567-572, 1992.

[68] J. Numaga, K. Matsuki, K. Tokunaga, T. Juji, and M. Mochizuki, "Analysis of human leukocyte antigen HLA-DR $\beta$ amino acid sequence in Vogt-Koyanagi-Harada syndrome," Investigative Ophthalmology and Visual Science, vol. 32, no. 7, pp. 1958-1961, 1991.

[69] A. Iqniebi, A. Gaafar, A. Sheereen et al., "HLA-DRB1 among patients with Vogt-Koyanagi-Harada disease in Saudi Arabia," Molecular Vision, vol. 15, pp. 1876-1880, 2009.

[70] A. C. Goldberg, J. H. Yamamoto, J. M. Chiarella et al., "HLADRB1 $^{*}, 0405$ is the predominant allele in Brazilian patients with Vogt-Koyanagi-Harada disease," Human Immunology, vol. 59, no. 3, pp. 183-188, 1998.

[71] X. Lin and X. Zhong, "A clinical analysis of 30 cases of sympathetic ophthalmia," Yan ke xue bao, vol. 12, no. 4, pp. 191192, 1996.

[72] C. P. Castiblanco and R. A. Adelman, "Sympathetic ophthalmia," Graefe's Archive for Clinical and Experimental Ophthalmology, vol. 247, no. 3, pp. 289-302, 2009.

[73] A. Galor, J. L. Davis, H. W. Flynn Jr. et al., "Sympathetic ophthalmia: incidence of ocular complications and vision loss in the sympathizing eye," The American Journal of Ophthalmology, vol. 148, no. 5, pp. 704.e2-710.e2, 2009.

[74] C.-C. Chan, F. G. Roberge, S. M. Whitcup, and R. B. Nussenblatt, "32 cases of sympathetic ophthalmia: a retrospective study at the National Eye Institute, Bethesda, Md, from 1982 to 1992," Archives of Ophthalmology, vol. 113, no. 5, pp. 597-600, 1995.

[75] S.-J. Sheu, H.-K. Kou, and J.-F. Chen, "Prognostic factors for Vogt-Koyanagi-Harada disease," Journal of the Chinese Medical Association, vol. 66, no. 3, pp. 148-154, 2003.

[76] S.-J. Sheu, H.-K. Kou, and J.-F. Chen, "Significant prognostic factors for Vogt-Koyanagi-Harada disease in the early stage," Kaohsiung Journal of Medical Sciences, vol. 20, no. 3, pp. 97-105, 2004.

[77] C. Kiyomoto, M. Imaizumi, K. Kimoto, H. Abe, S. Nakano, and K. Nakatsuka, "Vogt-Koyanagi-Harada disease in elderly Japanese patients," International Ophthalmology, vol. 27, no. 2-3, pp. 149-153, 2007.

[78] T. Y. Y. Lai, R. P. S. Chan, C. K. M. Chan, and D. S. C. Lam, "Effects of the duration of initial oral corticosteroid treatment on the recurrence of inflammation in Vogt-Koyanagi-Harada disease," Eye, vol. 23, no. 3, pp. 543-548, 2009.

[79] S.-P. Chee, A. Jap, and C. M. G. Cheung, "The prognostic value of angiography in Vogt-Koyanagi-Harada disease," The American Journal of Ophthalmology, vol. 150, no. 6, pp. 888-893, 2010.

[80] M. M. Yang, T. Y. Lai, P. O. Tam et al., "Complement factor $\mathrm{H}$ and interleukin gene polymorphisms in patients with noninfectious intermediate and posterior uveitis," Molecular Vision, vol. 18, pp. 1865-1872, 2012.
[81] S. Morita, Y. Nakamaru, N. Obara, M. Masuya, and S. Fukuda, "Characteristics and prognosis of hearing loss associated with Vogt-Koyanagi-Harada disease," Audiology and Neurotology, vol. 19, no. 1, pp. 49-56, 2013. 


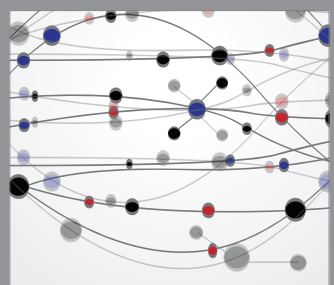

The Scientific World Journal
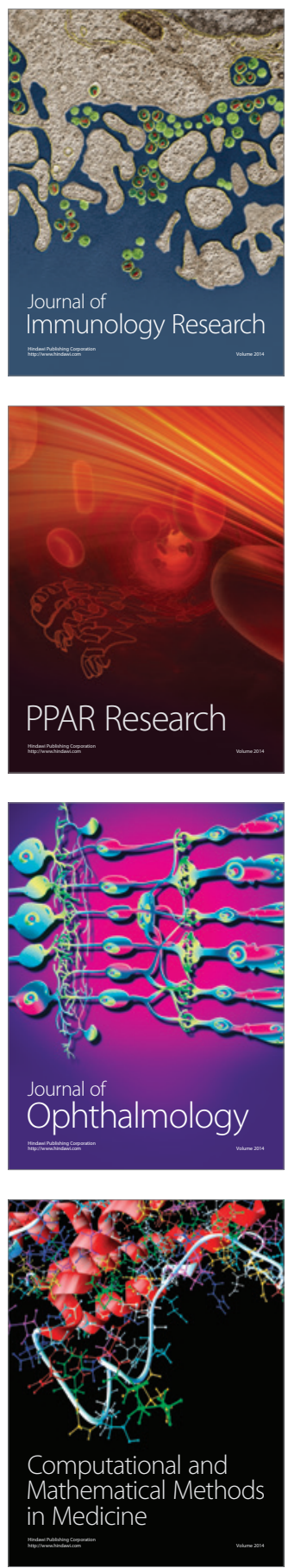

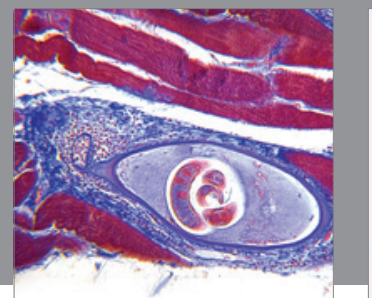

Gastroenterology

Research and Practice
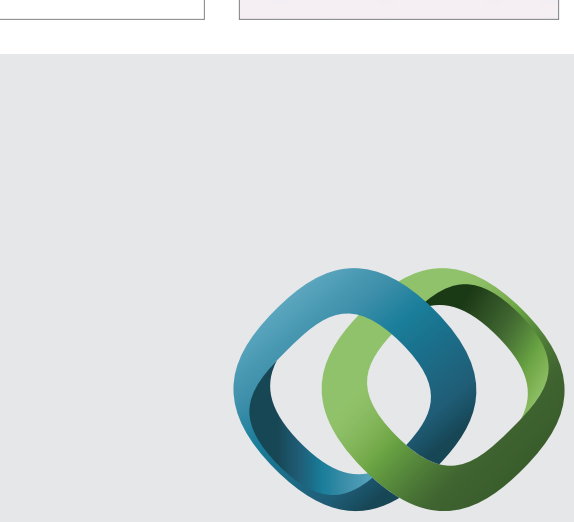

\section{Hindawi}

Submit your manuscripts at

http://www.hindawi.com
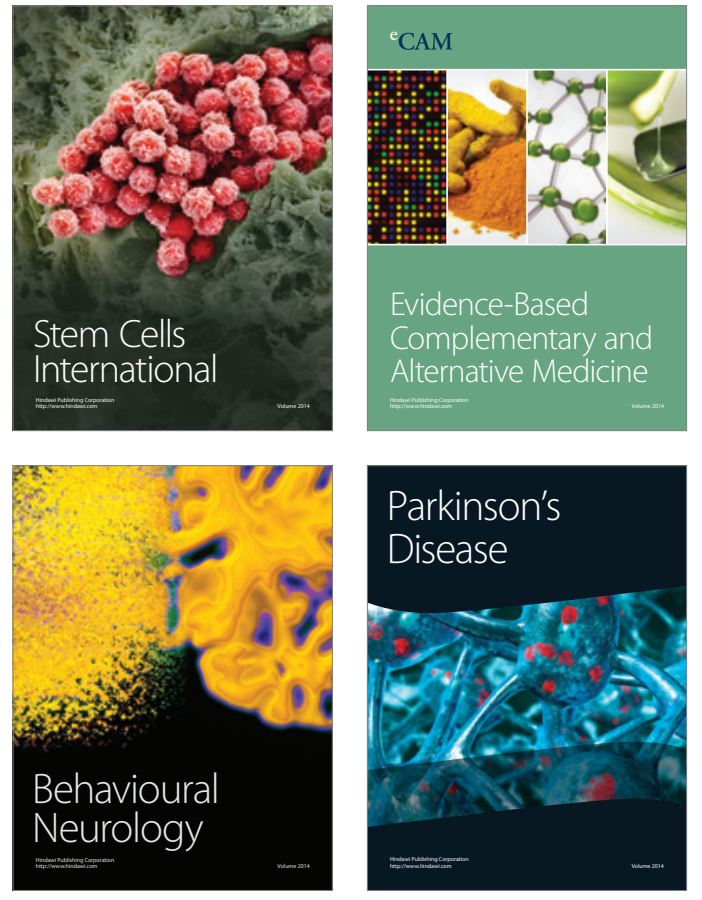
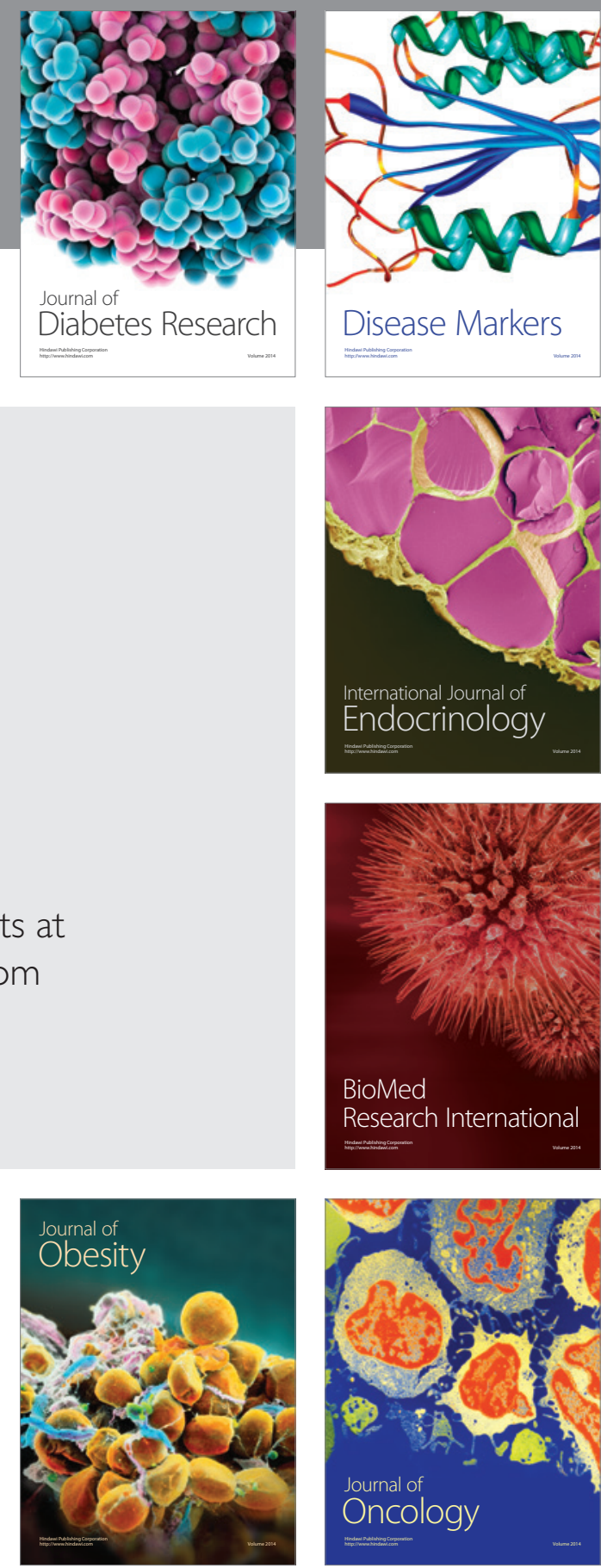

Disease Markers
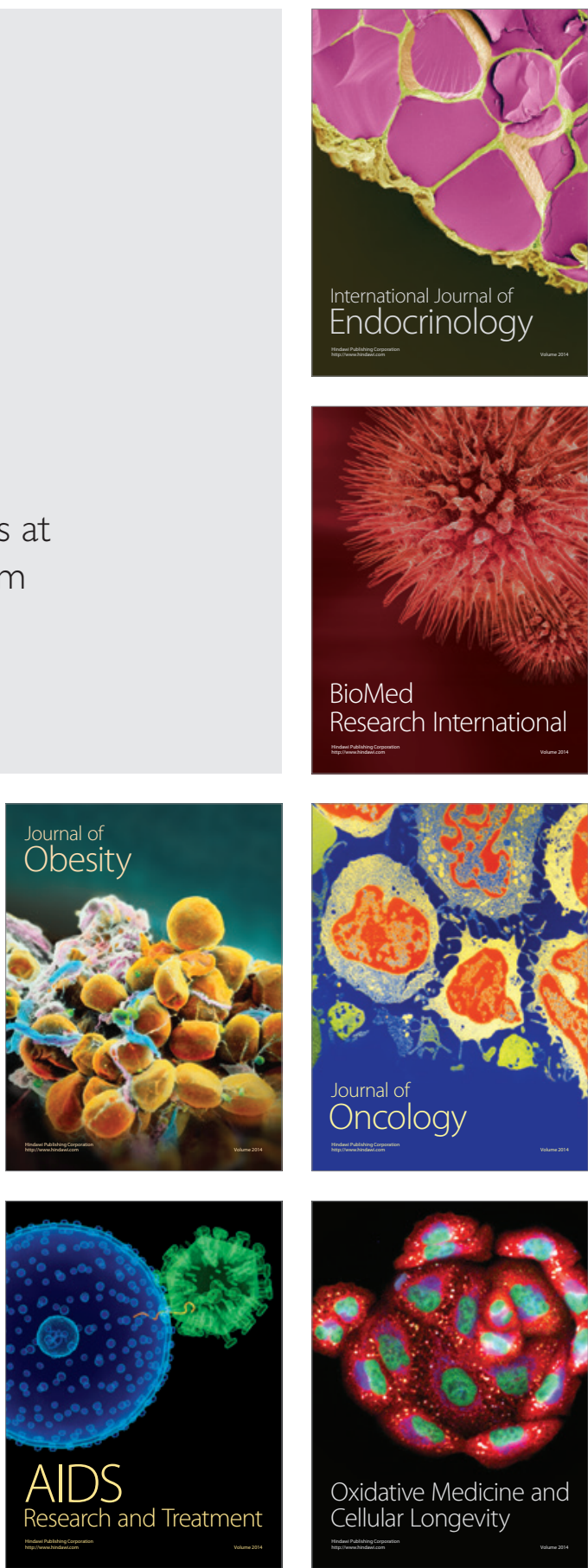